\title{
REACTION OF DICHLOROTRIAZINYL REACTIVE DYES WITH CELLULOSE AND SIMULTANEOUS DIFFUSION IN CELLULOSE
}

\author{
By Zenzo Morita, Isao Nishikawa and Hiromi Motomura \\ (Faculty of Engineering, Tokyo University of Agriculture \\ and Technology, Koganei, Tokyo, 184 Japan)
}

\begin{abstract}
Synopsis
The pseudofirst-order rate constants, $k_{\text {cell }}$, of the reaction with cellulose for five dichlorotriazinyl reactive dyes were measured at $30^{\circ} \mathrm{C}$ by the method of cylindrical film roll. The ratio, $P\left(=k_{\mathrm{w}} / k_{\mathrm{cell}}\right)$, of the pseudofirst-order rate constant, $k_{\mathrm{w}}$, of the hydrolysis in cellulose to the $k_{\mathrm{cell}}$ was examined by two methods. The $\log k_{\text {cell }}$ versus $\mathrm{pH}$ plots were similar to those for the hydrolysis measured by Ingamells et al. They were linear below $\mathrm{pH} 10$ and fell off at about $\mathrm{pH} 10$ except for C.I. Reactive Red 1 and Red 2. The diffusion coefficients of the active and hydrolyzed species were constant over the $\mathrm{pH}$ range $7-12$. The diffusion and reaction behaviors were exceptional for Orange 1, Red 1 and Red 2 among the dichlorotriazinyl dyes. Namely, the hydrolysis of Orange 1 in cellulose was very fast at high $\mathrm{pH}$, and Red 1 and Red 2 had a large diffusion coefficient in spite of the moderate adsorptivity and showed a particular pH-dependence of $\log k_{\text {cell }}$. The value of $P$, in general, decreased with the increase in ionic strength and increased with the increase in $\mathrm{pH}$, though it varied with dyes.
\end{abstract}

\section{INTRODUCTION}

The fundamental studies on the reactive dyeing have been carried out mainly by ICI chemists by using dichlorotriazinyl dyes. Sumner ${ }^{1)}$ measured an alkali adsorption by cellulose and showed a constancy of the affinity of dichlorotriazinyl dyes for cellulose up to very high $\mathrm{pH}$ by taking the alkali adsorption by cellulose into consideration. Ingamells, Sumner and Williams ${ }^{2}$ examined the hydrolysis and alcoholysis of many di- and monochlorotriazinyl dyes and found the pseudofirstorder reaction mechanism and characteristic relations between the pseudofirst-order reaction rate constants and $\mathrm{pH}$. The apparent decrease in the second-order reaction rate constants at high $\mathrm{pH}$ found by them ${ }^{2}$ ) was interpreted as being due to an ionization of the imino bridge group. ${ }^{3)}$ Preston and $\mathrm{Fern}^{4}$ ) examined the reaction with cellulose accompanied by the hydrolysis and confirmed that the reaction with cellulose was considerably faster than the hydrolysis. They showed the existance of various kinds of binding mechanisms because of bifunctionality of dichlorotriazinyl dyes, and examined the stability of the bonding between dye and cellulose. Dawson, Fern and Preston ${ }^{5)}$ studied the reaction of dyes with primary and secondary hydroxyl groups of cellulose. On the basis of these results, the theories on the reactive dyeing, ${ }^{6,7)}$ on the pad dyeing ${ }^{8}$ ) and on the batch dyeing $^{9)}$ have been reported.

In the previous paper, ${ }^{10-12)}$ the authors studied the diffusion with simultaneous reaction for three dichlorotriazinyl reactive dyes (C.I. Reactive Yellow 4 , Orange 1 and Red 1) by the use of cylindrical film roll method. Over the range from neutral to weakly alkaline conditions, the experimental concentration profiles of the active and immobilized species for the dyes in cellulose agreed with the theoretical profiles described by the diffusion equation where the diffusion was accompanied by the pseudofirst-order reaction with cellulose and with water in cellulose. In highly alkaline region, the concentration profiles of the immobilized species agreed with the theoretical profiles of the fixed species. The experimental profiles of re- 
moved species for Orange 1 and Red 1 did not agree with the theoretical profiles, because of a considerable hydrolysis of these dyes in cellulose. The $\mathrm{pH}$-dependence of the pseudofirst-order rate constants for the reaction with cellulose obtained by this method was similar to that reported by Ingamells et $\mathrm{al}^{2}{ }^{2)}$ In order to explain the apparent decrease in the diffusion coefficient due to the hydrolysis in cellulose under highly alkaline conditions, the authors added a term of the hydrolysis in cellulose to the diffusion equation. ${ }^{12}$ ) By estimating the ratio of a rate constant of the hydrolysis in cellulose to that of the reaction with cellulose using an alternative experiment, it was confirmed that some of the dichlorotriazinyl dyes were hydrolyzed considerably in cellulose.

In the present paper, five dichlorotriazinyl reactive dyes are examined by the same methods as reported in the previous papers ${ }^{10-12)}$ in order to obtain general dyeing properties of dichlorotriazinyl dyes. These eight dyes, including three dyes examined previously, ${ }^{10-12)}$ are the same as used by Ingamells et al. ${ }^{2}$ In this paper, the hydrolysis and the reaction with cellulose will be compared, and relationships among the diffusion, the reaction with cellulose and with water in cellulose, the hydrolysis in the dyebath, the affinity and the molecular structure will be also discussed.

\section{EXPERIMENTAL}

\subsection{Materials and Experimental Conditions}

Dichlorotriazinyl dyes used, including three dyes examined previously, are listed in Table 1. Commercial dye samples were used without further purification, since the absence of colored impurities was checked by paper chromatography. Kolthoff's buffer solutions were used to adjust the $\mathrm{pH}$ of the dyebath and sodium sulfate to adjust the ionic strength. The experimental conditions for diffusion are shown in Table 2. The apparatus for diffusion experiments was the same as reported previously. ${ }^{10-12)}$ The chemicals used were of reagent grade.

\subsection{Simultaneous Reaction with Cellulose and Water}

A cellophane film scoured was dyed uniformly by the active species of a reactive dye in a cold and neutral dyebath containing sodium sulfate of the same ionic strength as that of the following experiment. The film was rolled in several layers (the number of layers: $i$ ) on a glass tube. Another film, which was scoured by distilled water and immersed in the buffer solution of the same ionic strength, was rolled in five layers on the film roll (the number of layers from inner surface: $i$ ) (c.f. Fig, 1). A special care was exercised to prevent the hydrolysis of active species before the experiment of reaction. The film roll was immediately immersed into a buffer solution of the same ionic strength at $30^{\circ} \mathrm{C}$ for a sufficient length of time. After the reaction, it was opened and cut in half. The film cut off was immediately scoured in boiling water to remove the unreacted dyes. After drying, the optical densities of the respective layers of both the films were measured at a wavelength of maximum absorption of the dye by a UVIDEC-505 spectrophotometer (Japan Spectroscopic Co., Ltd.).

Table 1. Dichlorotriazinyl Reactive Dyes Used.

\begin{tabular}{l|c|c|l|c}
\hline C.I. Reactive & Abbreviation & C. 1. No. & \multicolumn{1}{|c|}{ Commercial dyes used } & $\begin{array}{c}\text { Affinity } \\
-3 \mu^{\circ} \\
\left(\mathrm{kJ} \mathrm{mol}^{-1}\right)\end{array}$ \\
\hline Yellow 1 & Y1 & 18971 & Mikacion Brilliant Yellow 6GS & 8.0 \\
Yellow 4 & Y4 & 13190 & Mikacion Yellow RS & 16.4 \\
Orange 1 & O1 & 17907 & Mikacion Brilliant Orange GS & 13.0 \\
Red 1 & R1 & 18158 & Mikacion Brilliant Red 2BS & 7.6 \\
Red 2 & R2 & 18200 & Mikacion Brilliant Red 5BS & 10.5 \\
Red 8 & R8 & 17908 & Mikacion Scarlet GS & 13.0 \\
Blue 1 & B1 & Ref. 13 & Mikacion Blue 3GS & 8.8 \\
Blue 4 & B4 & 61205 & Mikacion Brilliant Blue RS & 6.7 \\
\hline
\end{tabular}


Table 2. Experimental Conditions. $\quad\left(I=0.15,2 \mathrm{~g} / \mathrm{dm}^{3} \mathrm{dye}\right)^{*}$

\begin{tabular}{|c|c|c|c|c|c|c|c|c|c|}
\hline C.I. Reactive & \multicolumn{3}{|c|}{ Yellow 1} & \multicolumn{3}{|c|}{ Red 2} & Red 8 & Blue 1 & Blue 4 \\
\hline Temperature $\left({ }^{\circ} \mathrm{C}\right)$ & 25 & 30 & 35 & 25 & 30 & 35 & 30 & 30 & 30 \\
\hline $\begin{array}{l}\text { Conc. of dyebath } \\
\left(\times 10^{-3} \mathrm{~mol} / \mathrm{dm}^{3}\right)\end{array}$ & \multicolumn{3}{|c|}{1.2} & \multicolumn{3}{|c|}{1.9} & 1.7 & 1.3 & 1.4 \\
\hline $\mathrm{pH}\left(20^{\circ} \mathrm{C}\right)$ & \multicolumn{9}{|c|}{ Diffusion time (min) } \\
\hline 6.8 & 300 & 300 & 300 & 120 & 120 & 120 & 360 & 240 & 240 \\
\hline 7.6 & - & 300 & - & - & 120 & - & 360 & 240 & - \\
\hline 8.4 & - & 300 & $\begin{array}{l}300 \\
360\end{array}$ & $\begin{array}{l}120 \\
180\end{array}$ & $\begin{array}{l}120 \\
180\end{array}$ & $\begin{array}{l}120 \\
180\end{array}$ & - & 240 & - \\
\hline 8.8 & $\begin{array}{l}300 \\
360\end{array}$ & - & - & $\begin{array}{l}120 \\
180\end{array}$ & $\begin{array}{l}120 \\
240\end{array}$ & $\begin{array}{l}120 \\
180\end{array}$ & 180 & - & - \\
\hline 9.0 & $\begin{array}{l}300 \\
360\end{array}$ & $\begin{array}{l}300 \\
360\end{array}$ & $\begin{array}{l}300 \\
360\end{array}$ & - & - & - & $\begin{array}{l}180 \\
240\end{array}$ & $\begin{array}{l}240 \\
300\end{array}$ & $\begin{array}{l}240 \\
300\end{array}$ \\
\hline 9.2 & - & - & - & $\begin{array}{l}120 \\
180\end{array}$ & 120 & $\begin{array}{l}120 \\
180\end{array}$ & - & - & - \\
\hline 9.6 & $\begin{array}{l}300 \\
360\end{array}$ & $\begin{array}{l}300 \\
360\end{array}$ & $\begin{array}{l}300 \\
360\end{array}$ & - & 120 & - & $\begin{array}{l}180 \\
300\end{array}$ & $\begin{array}{l}240 \\
480\end{array}$ & $\begin{array}{l}240 \\
300\end{array}$ \\
\hline 9.8 & - & $\begin{array}{l}300 \\
360\end{array}$ & - & - & - & - & - & - & - \\
\hline 10.0 & - & - & - & - & $\begin{array}{r}60 \\
120\end{array}$ & - & $\begin{array}{l}120 \\
180\end{array}$ & $\begin{array}{l}240 \\
300\end{array}$ & $\begin{array}{l}240 \\
300\end{array}$ \\
\hline 10.6 & - & $\begin{array}{l}300 \\
360\end{array}$ & - & - & $\begin{array}{r}60 \\
120\end{array}$ & - & $\begin{array}{l}120 \\
180\end{array}$ & $\begin{array}{l}240 \\
480\end{array}$ & $\begin{array}{l}240 \\
300\end{array}$ \\
\hline 11.0 & - & $\begin{array}{l}240 \\
300\end{array}$ & - & - & 60 & - & $\begin{array}{r}60 \\
120\end{array}$ & $\begin{array}{l}180 \\
360\end{array}$ & $\begin{array}{l}180 \\
240\end{array}$ \\
\hline 11.7 & - & $\begin{array}{l}240 \\
300\end{array}$ & - & - & - & - & $\begin{array}{r}60 \\
120\end{array}$ & $\begin{array}{l}180 \\
360\end{array}$ & $\begin{array}{l}180 \\
240\end{array}$ \\
\hline
\end{tabular}

* I: lonic strength

\section{RESULTS AND DISCUSSION}

\subsection{Reaction with Cellulose and Water in Cellulose}

As the dichlorotriazinyl reactive dyes have a high reactivity, the higher the $\mathrm{pH}$, the faster the hydrolysis in cellulose may become. If the active species dyed uniformly in the cold and neutral dyebath remained in the initial state and the reactions are first- or pseudofirst-order, the rate of reaction with cellulose and water for the active species is given by eq. (1),

$$
\frac{\mathrm{d} c}{\mathrm{~d} t}=-\left(k_{\mathrm{cell}}+k_{\mathrm{w}}\right) C
$$

where $C(\mathrm{~mol} / \mathrm{kg})$ is a concentration of the active species, $t(\mathrm{~min})$ is time, $k_{\text {cell }}$ and $k_{\mathrm{w}}\left(\mathrm{min}^{-1}\right)$ are the pseudofirst-order rate constants of the reaction with cellulose and water, respectively.

Denoting $C=C_{1}$ (at $t=0$ ) as the initial concentration of active species in cellophane, the solution of eq. (1) is given as

$$
C=C_{1} \exp \left\{-\left(k_{\text {cell }}+k_{\mathrm{w}}\right) t\right\}
$$

The concentration $C_{\text {cell }}^{*}(\mathrm{~mol} / \mathrm{kg})$ of fixed species which have reacted with cellulose at a reaction time $t$ is given by

$$
\begin{aligned}
C_{\mathrm{ce} \| 1}^{*} & =\int_{0}^{t} k_{\mathrm{cell}} C \mathrm{~d} t \\
& =\frac{C_{1}}{1+P}\left[1-\exp \left\{-(1+P) k_{\mathrm{cell}} t\right\}\right]
\end{aligned}
$$

where $P=k_{\mathrm{w}} / k_{\text {cell }}$. Then, the fixation ratio $Q_{1}$ is given by eq. (4) and has a limiting value given by eq. (5): $:^{12)}$ 


$$
\begin{aligned}
Q_{\mathrm{I}} & =\frac{C_{\text {cell }}^{*}}{C_{1}}=\frac{1}{1+P}\left(1-\exp \left|-(1+P) k_{\text {cell }}\right| 1\right) \\
& \div \frac{1}{1+P}, \quad(1+P) k_{\text {cell }} t>1
\end{aligned}
$$

Some of the results measured are shown in Fig. 1. It was found that the active species in the inner layers remained in the initial state, as the total concentration in the inner layers did not change during the reaction. As the experimental diffusion profiles for the removed and immobilized species agreed well with the theoretical profiles for the active and fixed species under weakly
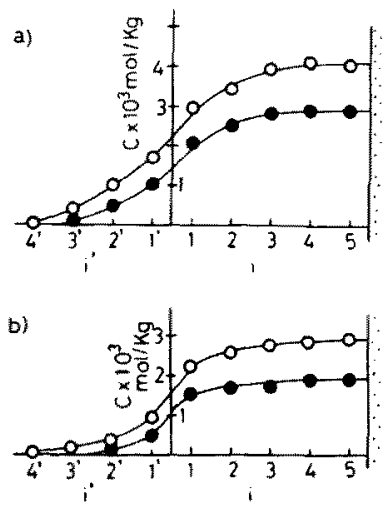

Fig. 1. Concentration profiles for C. I, Reactive Yellow 1 (a) and Blue 1 (b) after the reaction with cellulose and water in cellulose at $\mathrm{pH} 10.6,30^{\circ} \mathrm{C}, I=0.15$ and $t=90 \mathrm{~min}(P=$ 0.40 for Yellow 1 and 0.45 for Blue 1). Open and closed circles denote the total concentration and the concentration of fixed species, respectively. alkaline conditions, the presence of hydrolyzed species in the original dye samples may be regarded to be negligible (c.f. Fig. 2).

From the optical densities of the washed-off and unwashed-off films, the values of $P$ were calculated as are listed in Table 3. The values of $P$ for dichlorotriazinyl dyes except for C.I. Reactive Orange 1 were in the range of $0.2-0.9$ above $\mathrm{pH} 10.5$ and varied with dyes. Thus, the hydrolysis of these dyes takes place considerably in cellulose and accordingly the fixation ratio decreases down to $50 \%$. As in the case of the previous paper, ${ }^{12)}$ the values of $P$ for Orange 1 are
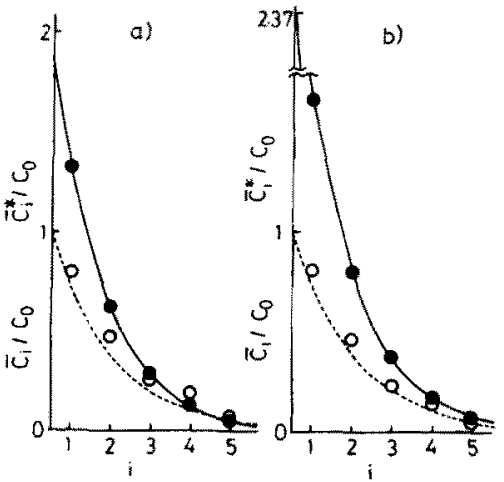

Fig. 2. Concentration profiles for removed (0) and immobilized species (-) for C. I. Reactive Blue 4 at $30^{\circ} \mathrm{C}, \mathrm{pH} 9.0$ and $I=0.15$.

Curves are the theoretical profiles for active $(-.-)$ ) and fixed species ( - ) described for $D=3.9 \times 10^{-7} \mathrm{~cm}^{2} / \mathrm{min}, k_{\text {cell }}=0.0079 \mathrm{~min}^{-1}$ and $P=0.5$. Diffusion time: a) $t=240 \mathrm{~min}$, b) $t=300 \mathrm{~min}$.

Table 3. Values of $P\left(=k_{\mathrm{w}} / k_{\text {cell }}\right)$ at Various Ionic Strengths, $l$, at $30^{\circ} \mathrm{C}$.

\begin{tabular}{l|c|c|c|c|c}
\hline \multirow{2}{*}{ C.l. Reactive } & \multirow{2}{*}{$\mathrm{pH}$} & \multirow{2}{*}{$\begin{array}{c}\text { Time } \\
(\mathrm{min})\end{array}$} & \multicolumn{3}{|c}{ Values of $P$} \\
\cline { 4 - 6 } & & $I=0.15$ & $I=0.5$ & $I=1.0$ \\
\hline Yellow 1 & 10.6 & 90 & 0.40 & 0.31 & 0.26 \\
Yellow 4 & 10.6 & 90 & 0.65 & 0.62 & 0.60 \\
Orange 1 & 10.6 & 90 & 1.68 & 1.51 & 1.30 \\
& 12.0 & 90 & 1.70 & 1.50 & 1.32 \\
Red 1 & 12.0 & 60 & 0.51 & 0.39 & 0.38 \\
Red 2 & 12.0 & 30 & 0.46 & 0.40 & 0.23 \\
Red 8 & 10.6 & 90 & 0.70 & 0.69 & 0.61 \\
Blue 1 & 10.6 & 90 & 0.54 & 0.48 & 0.46 \\
Blue 4 & 10.6 & 90 & 0.90 & 0.88 & 0.83 \\
\hline
\end{tabular}


large in comparison with those for the other dyes.

With the increase in ionic strength, the total concentration adsorbed in the dye solution increased, while the values of $P$ decreased clearly. This fact supports the view by Rys and Zollinger ${ }^{15}$ ) that the hydrolysis in cellulose may occur mainly in the mobile state. However, no consistent relation was found between the affinity (Table 1) ${ }^{14}$ ) and the values of $P$. In practice, an addition of a large amount of electrolytes is essential to obtain a high fixation ratio.

\subsection{Reaction with Cellulose and Simultaneous Diffusion}

The concentration profiles for the active and immobilized species in cellulose agreed well with the theoretical profiles described by the diffusion equation, ${ }^{10,12)}$ as shown in Fig. 2:

$$
\frac{\partial C}{\partial t}=D \frac{\partial^{2} C}{\partial x^{2}}-\left(k_{\mathrm{cell}}+k_{\mathrm{w}}\right) C
$$

where $D\left(\mathrm{~cm}^{2} / \mathrm{min}\right)$ is the diffusion coefficient of the active species, $x(\mathrm{~cm})$ is the distance and the other symbols are same as before.

By a sufficient feed of stock solutions of dye and buffer, the surface concentration $C_{0}$ was kept constant throughout the diffusion experiment, i.e. the concentration of hydrolyzed species in the dyebath was kept negligible during the diffusion. The value of $C_{0}$ was obtained by extrapolating the experimental profile for the active species. The values of $D$ for the active species in the high $\mathrm{pH}$ region were estimated from those in the neutral region, since it was confirmed that those for hydrolyzed species were constant over the whole $\mathrm{pH}$ range examined. By the use of the values of $C_{\mathrm{o}}$ and $D$ thus obtained, the values of $k_{\text {cell }}$ and $k_{\mathrm{w}}$ were determined by fitting the theoretical profiles for the fixed and, if possible, active species to the experimental profiles for the immobilized and removed species.

The values of $k_{\text {cell }}$ obtained are shown in Fig. 3 and Table 4, where the $\mathrm{pH}$ values are slightly different from the true values, since the $\mathrm{pH}$ of an

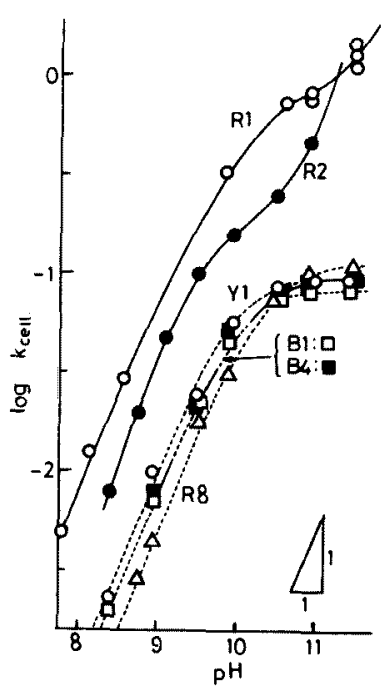

Fig. 3. Relationships between $\log k_{\text {cell }}$ and $\mathrm{pH}$ for dichlorotriazinyl dyes at $30^{\circ} \mathrm{C}$ and $I=0.15$. (O: Yellow 1, $\oplus$ : Red, $\bullet: \operatorname{Red} 2$, $\triangle: \operatorname{Red} 8, \square:$ Blue $1, \square:$ Blue 4)

Table 4. Pseudofirst-order Rate Constants of Reaction with Cellulose, $k_{\text {cell }}\left(\min ^{-1}\right)$.

\begin{tabular}{c|ccc|ccc|c|c|c}
\hline C.I. Reactive & \multicolumn{3}{|c|}{ Yellow 1 } & \multicolumn{3}{|c|}{ Red 2 } & Red 8 & Blue 1 & Blue 4 \\
\hline Temp. $\left({ }^{\circ} \mathrm{C}\right)$ & 25 & 30 & 35 & 25 & 30 & 35 & 30 & 30 & 30 \\
\hline $\mathrm{pH}\left(20^{\circ} \mathrm{C}\right)$ & & & & & & & & & \\
8.4 & & 0.0023 & 0.0029 & 0.0064 & 0.0080 & 0.0093 & & 0.0020 & \\
8.8 & 0.0048 & & & 0.016 & 0.020 & 0.023 & 0.0029 & & \\
9.0 & 0.0080 & 0.010 & 0.012 & & & & 0.0047 & 0.0070 & 0.0079 \\
9.2 & & & & 0.038 & 0.048 & 0.057 & & & \\
9.6 & 0.032 & 0.024 & 0.050 & & 0.10 & & 0.018 & 0.022 & 0.021 \\
9.8 & & 0.057 & & & & & & & \\
10.0 & & & & & 0.16 & & 0.031 & 0.046 & 0.053 \\
10.6 & & 0.088 & & & 0.25 & & 0.075 & 0.070 & 0.084 \\
11.0 & & 0.093 & & & 0.47 & & 0.10 & 0.081 & 0.089 \\
11.7 & & 0.093 & & & & & 0.11 & 0.083 & 0.091 \\
\hline
\end{tabular}


alkaline dyebath decreases with the increase in temperature. The relationships between $\log k_{\text {cell }}$ and $\mathrm{pH}$ appear to fall into two classes. Red 1 and Red 2 showed a particular behavior unlike the other dyes. However, the relationships for eight dyes are similar to those for hydrolysis observed by Ingamells et al. ${ }^{2)}$ The inflection points of the $\log k_{\text {cel1 }}$-pH curves were found near pH 10 except for Red 1 ( $\mathrm{pH} 9.8$ ), Red 2 (9.5) and Red 8(10.4). They coincide with the values of $\mathrm{p} K_{\mathrm{a}}$ obtained by Aspland and Johnson ${ }^{16}$ ) who analyzed the results of Ingamells et al., ${ }^{2)}$ except for Blue 4.

The factors to convert the value of $k_{\text {cell }}$ into that of the pseudofirst-order rate constant for hydrolysis of the corresponding dye under a definite condition varied with dyes.

The values of $D$ for the hydrolyzed and active species over the $\mathrm{pH}$ range $7-12$ are shown in Fig. 4. As no reaction with cellulose occurred at $\mathrm{pH} 7.6$, the values of $D$ for the active species at $\mathrm{pH} 6.8$ and 7.6 and the hydrolyzed species were calculated by the Sekido-Matsui method. ${ }^{17)}$ The values of $D$ were constant and a little higher for

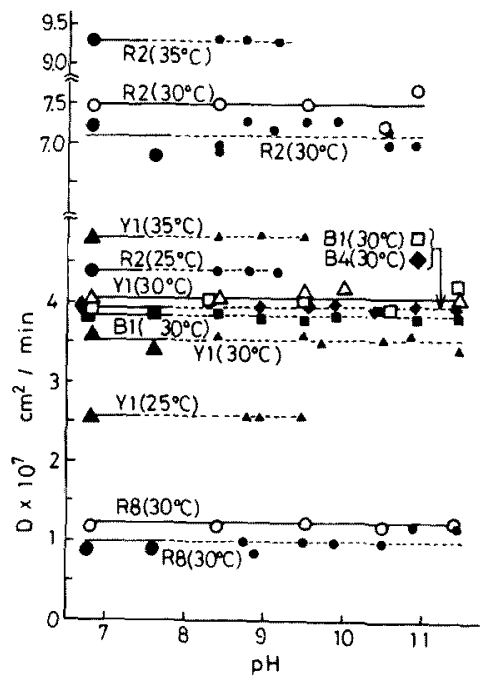

Fig. 4. Diffusion coefficients, $D\left(\mathrm{~cm}^{2} / \mathrm{min}\right)$, of active (closed symbols) and hydrolyzed species (open symbols) for dichlorotriazinyl dyes at $I=0.15$ (c.f. Table 1 for the abbreviations). Although the values of $D$ for active species at high $\mathrm{pH}$ were regarded as the first approximation to be equal to those at neutral $\mathrm{pH}$, they were corrected further to fit better. the hydrolyzed species than for the active species over the $\mathrm{pH}$ range examined.

The values of $C_{o}$ for the active and hydrolyzed species decreased in general with the increase in $\mathrm{pH}$ as shown in Fig. 5. The higher the values of $C_{0}$, the larger the extent of the decrease was. This is due not only to the increase in the cellulosate ion but also to the ionization of the phenolic hydroxyl group and the imino bridge group, if ionizable. The effect of the increase in the cellulosate ion on the adsorption of a model reactive dye with no ionizable, phenolic hydroxyl or imino, groups was analyzed by Sumner. ${ }^{1}$ ) It is one of the essential defects of reactive dyes that they are dyed or printed in the $\mathrm{pH}$ range where they have a small affinity and are washed off where they have a larger affinity. The differences in the values of $C_{o}$ among dichlorotriazinyl dyes appear to become smaller at higher $\mathrm{pH}$.

The values of $P$ obtained from the diffusion experiments at various pH's are shown in Fig. 6 and are in agreement with those obtained above at high $\mathrm{pH}$ except for Orange 1 and Red 2 (c.f. Table 3). ${ }^{12}$ They increased with the increase in $\mathrm{pH}$, implying a considerable hydrolysis of the active species in cellulose at high $\mathrm{pH}$.

The apparent diffusion coefficients, $D^{\prime}$, for dichlorotriazinyl dyes decrease with the increase

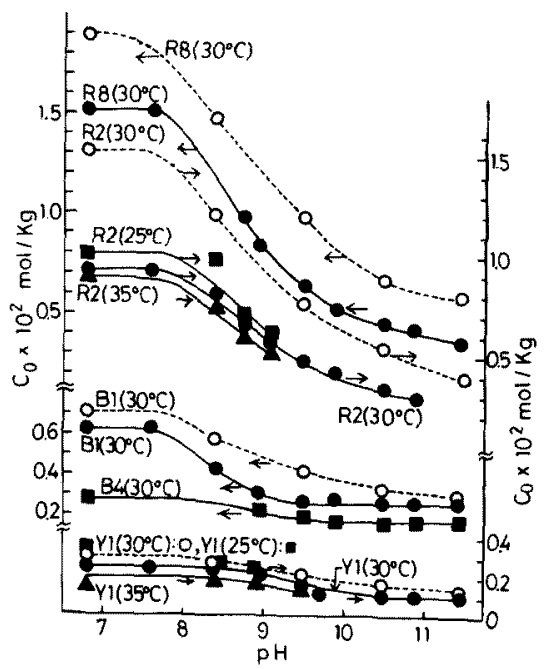

Fig. 5. Surface concentration, $C_{\mathrm{o}}(\mathrm{mol} / \mathrm{kg})$, of active (closed symbols) and hydrolyzed species (open symbols) at $I=0.15$. 


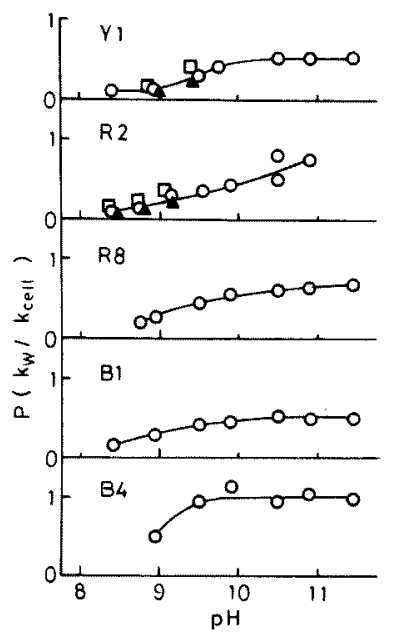

Fig. 6. Values of $P$ obtained from the diffusion experiment at $I=0.15$ and temperatures of $35(0), 30(\square)$ and $25^{\circ} \mathrm{C}(\mathbf{\Delta})$.

in $\mathrm{pH}$, if the effect of hydrolysis in cellulose is neglected. ${ }^{12)}$ In the present study, the main factor to give the decrease in $D^{\prime}$ was also found to be an increase in $P$. In the case of Orange $1^{12}$ ) and Red 2, the values of $P$ obtained from the diffusion experiments were larger than those shown in Table 3. Besides the effect of hydrolysis in cellulose, the apparent decrease in $D^{\prime}$ especially for Red 2 may be attributed to the concentration dependence of diffusion coefficient due to the large decrease in $C_{o}$ at high $\mathrm{pH}$, though it is not so clear from the results for the hydrolyzed species.

Blue 1 and Blue 4 are isomers. The reactivity of the $m$-isomer (Blue 4 ) is a little higher than that of the $p$-isomer (c.f. Table 4). This fact is similar to that of hydrolysis ${ }^{18}$ ) but contrary to the results reported by Ingamells et al. ${ }^{2}$ )

\subsection{Temperature Effect}

In order to elucidate the reaction and diffusion behaviors of dichlorotriazinyl dyes, the diffusion with simultaneous reaction for Yellow 1 and Red 2 was examined at 25 and $35^{\circ} \mathrm{C}$ below pH 10 by the same method as before. The results for $C_{o}, D$, $k_{\text {cell }}$ and $P$ are shown in Figs. 3, 4, 5, and 6 and Table 3. The activation energies of the reaction with cellulose, $E_{\mathrm{R}}$, and of the diffusion, $E_{\mathrm{D}}$, are estimated as shown in Table 5. The values of $E_{\mathrm{R}}$
Table 5. Activation Energies of Reaction with Cellulose,

$E_{\mathrm{R}}$, of Diffusion, $E_{\mathrm{D}}$ and of Hydrolysis, $E_{\mathbf{H}}$.

\begin{tabular}{c|c|c|c}
\hline C.I. Reactive & $\begin{array}{c}E_{\mathrm{R}} \\
\left(\mathrm{kJ} \mathrm{mol}^{-1}\right)\end{array}$ & $\begin{array}{c}E_{\mathrm{D}} \\
\left(\mathrm{kJ} \mathrm{mol}^{-1}\right)\end{array}$ & $\begin{array}{c}E_{\mathrm{H}}{ }^{6} \\
\left(\mathrm{~kJ} \mathrm{~mol}^{-1}\right)\end{array}$ \\
\hline Yellow 1 & 33.0 & 46.0 & 75.2 \\
Yellow 4 & - & - & 83.6 \\
Red 1 & - & - & 79.4 \\
Red 2 & 38.0 & 58.5 & 75.2 \\
Blue 4 & - & - & 79.4 \\
\hline
\end{tabular}

for dichlorotriazinyl dyes are very smaller than those for monochlorotriazinyl dyes, as expected. ${ }^{19)}$

From the hydrolytic reactions at 20, 30 and $40^{\circ} \mathrm{C}$ and $\mathrm{pH} 11$, Sumner and Vickerstaff estimated the activation energies of hydrolysis, $E_{\mathbf{H}}$, for four dyes as $75-84 \mathrm{~kJ} \mathrm{~mol}^{-1}$ (Table 5). ${ }^{6}$ These values are twice the $E_{\mathrm{R}}$ obtained here for Yellow 1 and Red 2. The fact that these dyes have different activation energies may be confirmed from the temperature dependence of $P$ for Yellow 1 and Red 2 shown in Fig. 6, i.e. the higher the temperature, the larger the values of $P$.

In the present study, the reaction of the first chlorine atom on triazine ring is taken into consideration. The reactivity of the second chlorine atom has been shown to be dependent on the conditions applied. ${ }^{4,5)}$ Since, when hydrolyzed, the reactivity of dichlorotriazinyl groups is considerably lowered, that of hydroxychlorotriazinyl groups may well be ignored.

\section{CONCLUSION}

1. The relationships between $\log k_{\text {cell }}$ and $\mathrm{pH}$ for dichlorotriazinyl dyes are classified into two types, one type being only for Red 1 and Red 2 .

2. The surface concentrations are in the range of $10^{-3} \mathrm{~mol} / \mathrm{kg}$ at $I=0.15$. Those for dyes with ionizable groups decrease with the increase in $\mathrm{pH}$.

3. The diffusion coefficients are constant over the $\mathrm{pH}$ range examined. Red 1 and Red 2 have a large value of $D$ in spite of the moderate adsorptivity.

4. The contribution of hydrolysis in cellulose is considerable in comparison with the other classes of reactive dyes.

5. It is profitable to apply the dichlorotriazinyl dyes at lower temperatures and near $\mathrm{pH} 10$ if the fixation ratio was regarded to be important, or 
at higher $\mathrm{pH}$ 's and temperatures in order to dye as rapidly as possible.

Acknowledgement: The authors would like to thank the Nippon Kayaku Co., Ltd., for the assistance of its staff in the preparation of this paper.

\section{REFERENCES}

1) H. H. Sumner, J. Soc. Dyers Colour., 76, $672(1960)$.

2) W. Ingamells, H. H. Sumner and G. Williams, J. Soc. Dyers Colour., 78, 274 (1962).

3) S. Horrobin, J. Chem. Soc, 1963, 4130.

4) C. Preston and A. S. Fern, Chimia, 15, 177 (1961).

5) T. L. Dawson, A. S. Fern and C. Preston, J. Soc. Dyers Colour., 76, 210 (1960).

6) H. H. Sumner and T. Vickerstaff, Melliand Textilber., 42, 1161 (1961).

7) I. D. Rattee, Melliand Textilber., 45, 782 (1964).

8) H. H. Sumner and C. D. Weston, Am. Dyest. Rep., 52, 442 (1963).

9) W. J. Marshall, Am. Dyest. Rep., 58(17), 19 (Aug. 25, 1969).
10) H. Motomura and Z. Morita, J. Appl. Polym. Sci., 21, 487 (1977).

11) H. Motomura and Z. Morita, Bull. Chem. Soc. Jpn., 51, 1332 (1978).

12) H. Motomura and Z. Morita, J. Appl. Polym. Sci., 24, 1747 (1979).

13) E. Siegel, "The Chemistry of Synthetic Dyes", Vol. VI, (Ed. by K. Venkataraman), Chap. 1, Academic Press, London, 1972.

14) "Procion Dyes in Textile Dyeing", ICI, 1962; through R.H. Peters, "Textile Chemistry", Vol. III, p. 615, Elsevier Scientific Publishing Co., Amsterdam, 1975.

15) P. Rys and H. Zollinger, "The Coloration of Textiles", (Ed. by C. L. Bird and W. S. Boston), Chap. 7, Dyers Company Publications Trust, 1975.

16) J. R. Aspland and A. Johnson, J. Soc. Dyers Colour., 81, 425 (1965).

17) M. Sekido and K. Matsui, Sen-i Gakkaishi, 20, 778 (1964).

18) M. Komaki, T. Kaneda, M. Hayashi, M. Hida and A. Yabe, Sen-i Gakkaishi, 29, T-546 (1973).

19) H. Motomura, G. Kawamura and Z. Morita, Meeting of the Society of Fiber Science and Technology, Oct. P. 68 (1980).

\section{ジクロルトリアジン系反応染料のセルロースとの反応 \\ とセルロース中の拡散}

\section{東京豊工大学工学部 森田全三，西川勇夫，本村洋美}

5 種類のジクロルトリアジン系反応染料のセルロース との擬一次反店速度定数 $k_{\text {cell }}$ 亡搪散係数を $30^{\circ} \mathrm{C}$ でフィ ルム巻層法によって調べた。セルロース中にお汀る擬一 次加水分解速度定数 $k_{\mathrm{w}}$ と $k_{\mathrm{cell}}$ との比 $P$ を $2 つ 0$ 万法で 調べた。 $\log k_{\mathrm{cell}} の \mathrm{pH}$ 依存性は Ingamellsらの求めた 加水分解速度のそれとよく一致した。その関係注 $\mathrm{pH} 10$ 以下では全ての染料に対して直線であるが，pH10以上
でRed 1 とRed 2 を除いて $\log k_{\text {cell }}$ がほば一定になる。 活性染料およひ放水分解染料の拡散係数は $\mathrm{pH} 7 \sim 12 \mathrm{~K}$ おいて一定である。Pの值は染料によってかなり差があ るが，一般にイオン強度と共に減少し， $\mathrm{pH}$ と共に增大 する。調べた染料の中で，PについてはOrange 1， $k_{\text {cell }}$ につてはRed 1 とRed 2 が例外的である。 